\title{
Tingkat Kesukaan Lebah Madu Apis mellifera L. Terhadap Pakan Tambahan Campuran Madu dan Jus Mengkudu
}

\author{
BUDIAMAN DAN B. PUTRANTO \\ Pusat Penelitian Lebah Madu, Lembaga Penelitian, Universitas Hasanuddin \\ Jl.Perintis Kemerdekaan Makassar 90245.
}

(diterima Oktober 2006, disetujui Juni 2007)

\begin{abstract}
The preference level of honey bees Apis mellifera $\mathrm{L}$. to the supplementary food of honey and nony juice mixture. Feeding supplementary food containing nony fruit juice was tested on honeybee colonies. The aims of this research were (1) to determine the preference level of honeybees to the supplementary food containing honey and nony mixture, (2) to identify the organoleptic properties of the produced honey-essence of nony, (3) to determine fiber content of produced honey-essence of nony, and (4) to identify the colours of honey produced. The design used in the experiment was Latin Square Design. There were four treatments of concentration used in this research, namely: A $(0 \%)$ as control, B $(12.5 \%), \mathrm{C}(25 \%)$ and D $(37.5 \%)$ in dilution of supplementary food an amount of 600 grams wich consist of nony fruit juice and water. Each composition of dilution were A $(300,0,300)$, B $(225,75,300), C(150,150,300)$ and D $(75,225,300)$. Every replication was done for six days with six days interval. The result were as follows: The higher concentration of nony juice in the food suplement, the smaller amount of food that were taken. The differences in the colour, the flavour and the taste of the artificial honey didn't depend on the amount of the food suplement taken by honey bees, but depend on nony fruits juice concentration in the honey produced. The higher concentration of nony fruit juice in the artificial honey produced the darken in colour, sour in taste and the weaken in flavour. Feeding with food suplement containing nony juice increases the fiber content in the honey,
\end{abstract}

KEYWORDS: Preference, nony, organoleptic, fiber

\section{PENDAHULUAN}

Madu merupakan bahan alami yang banyak mempunyai manfaat bagi kesehatan manusia. Selain sebagai bahan makanan yang bergizi dengan rasa yang enak, madu juga sudah sejak lama digunakan sebagai bahan obat. Sebagian besar masyarakat meman- faatkan madu dengan cara mengkonsumsinya secara langsung dan sebagian menggunakan sebagai bahan ramuan dalam berbagai produk obat dan makanan karena rasa dan aromanya banyak disukai oleh orang.

Seperti madu, mengkudu juga merupakan bahan alami yang sangat populer penggunaannya sebagai obat berkhasiat karena mengandung ber- 
bagai senyawa aktif yang mampu mengobati berbagai penyakit. Sayangnya aroma dan rasa buah mengkudu tidak enak akibat berbagai senyawa asam organik yang terdapat di dalamnya, terutama pada buah yang telah matang.

Untuk meningkatkan kandungan gizi dari madu, lebah dapat diberi pakan tambahan dalam bentuk sirup yang dicampur dengan bahan lain yang mengandung gizi yang diinginkan. Pemberian pakan tambahan tersebut disebut dengan metode cepat atau express method dengan tujuan untuk menghasilkan madu dengan kandungan gizi tertentu secara cepat dan alami (Ioyrish 1978).

Berdasarkan pemikiran tersebut, telah dilakukan penelitian yang berhubungan dengan pemberian pakan tambahan berupa larutan campuran madu dan jus buah mengkudu kepada lebah madu Apis mellifera L. Dengan mengkonsumsi pakan tambahan yang mengandung mengkudu diharapkan lebah menghasilkan madu sari mengkudu yang mengandung khasiat sinergi madu dan mengkudu secara alami. Istilah madusari mengkudu, untuk selanjutnya disingkat MSM, digunakan untuk membedakannya dengan madu mengkudu yang berasal dari nektar bunga mengkudu yang dikumpulkan oleh lebah dari suatu hutan maupun kebun yang didominasi oleh tumbuhan mengkudu.
Tujuan dari penelitian ini adalah (1) Menentukan tingkat preferensi lebah terhadap pakan tambahan berupa campuran madu dan jus buah mengkudu pada berbagai konsentrasi, (2) Mengetahui secara organoleptik, aroma, dan rasa MSM, (3) Mengetahui kandungan serat buah mengkudu dalam MSM, (4) Mengetahui warna dasar MSM.

\section{BAHAN DAN METODE}

\section{Bahan dan Alat}

Bahan yang digunakan dalam penelitian adalah air suling, alkohol, asam sulfat $0,3 \mathrm{~N}$, jus buah mengkudu, empat koloni lebah Apis mellifera L. yang masing-masing terdiri atas enam sisiran, madu ternak dan natrium hidroksida $1,5 \mathrm{~N}$. Sedang alat utama yang digunakan adalah juicer (Phillips), timbangan digital dengan ketelitian 0,1 gram (Nagata LCS3000), seperangkat alat penentuan kadar serat kasar.

\section{Rancangan Percobaan}

Percobaan lapangan terdiri atas empat perlakuan dengan konsentrasi mengkudu masing-masing A $(0 \%)$ sebagai kontrol, B $(12,5 \%)$, C (25\%) dan D $(37,5 \%)$ dalam larutan pakan tambahan seberat 600 gram yang terdiri atas madu, jus buah mengkudu dan air. Komposisi masing-masing larutan adalah A $(300,0,300), \quad \mathrm{B}$ $(225,75,300), \mathrm{C}(150,150,300)$ dan 
D $(75,225,300)$. Rancangan yang digunakan adalah rancangan Bujur Sangkar Latin yang terdiri atas empat perlakuan yang diterapkan pada empat koloni lebah Apis mellifera L. Setiap perlakuan diulang sebanyak empat kali. Pada setiap kali ulangan, setiap koloni mendapatkan perlakuan yang berbeda. Setiap ulangan dilakukan selama enam hari dengan masa tenggang selama satu minggu.

\section{Indikator dan Parameter Pengujian}

Indikator yang diamati berupa warna, aroma, dan rasa MSM, sedang parameter yang diukur berupa banyaknya pakan yang diambil dan kandungan serat MSM.

\section{Pengamataan, Indikator, dan Pengukuran Parameter}

\section{Produksi MSM}

- Sebelum diberikan perlakuan, koloni lebah diseragamkan kekuatan koloninya dengan cara mempertukarkan sisiran dari koloni yang padat dengan koloni yang kurang padat selama satu minggu dan madu yang berada di tiap koloni diambil dengan menggunakan spuit.

- Ditimbang frame feeder (tempat pakan) dan pakan tambahan sesuai perlakuan (A, B, C dan D) sampai mencapai berat yang telah ditetapkan (b gram), kemudian diletakkan di dalam kotak koloni berdampingan dengan sisiran/bingkai.

- Pemberian pakan dilakukan setiap hari pada pukul 17.00 selama enam hari pada masing-masing koloni.

- Ditimbang frame feeder dan pakan yang tersisa setelah 24 jam pemberian (c gram). Banyaknya pakan tambahan yang dikonsumsi $=(b-c)$.

- Pada hari ke-tujuh, madu yang dihasilkan dipanen. Pemanenan dilakukan tanpa merusak sarang lebah dengan menggunakan spuit terhadap sel sarang lebah yang terbuka dan mengandung madu saja. Hal ini dilakukan karena sarang lebah tersebut masih akan digunakan dalam pemberian perlakuan periode berikutnya.

- Hasil madu yang diperoleh dikumpulkan berdasarkan perlakuan yang diberikan dan selanjutnya dibagi-bagi untuk analisis lanjutan.

\section{Pengamatan Organoleptis}

Pengamatan organoleptis mencakup warna, aroma, dan rasa MSM yang dihasilkan oleh lebah.

Penetapan Kadar Serat. Analisis kadar serat kasar madu, jus buah mengkudu, pakan tambahan dan MSM dilakukan dengan cara sebagai berikut : Ditimbang masing-masing 2-3 gram sampel dalam gelas piala, kemudian ditambahkan $50 \mathrm{ml} \mathrm{H}_{2} \mathrm{SO}_{4} \quad 0.3 \mathrm{~N}$ dan dididihkan selama 30 menit. Selanjut- 
nya ditambah $25 \mathrm{ml} \mathrm{NaOH} 1,5 \mathrm{~N}$ dan dididihkan kembali selama 30 menit. Disaring dengan sintered glass sambil diisap dengan pompa vakum. Hasilnya dicuci berturut-turut dengan $50 \mathrm{ml}$ air panas, $50 \mathrm{ml} \mathrm{H}_{2} \mathrm{SO}_{4} 0,3 \mathrm{~N}, 50 \mathrm{ml}$ air panas, dan $50 \mathrm{ml}$ alkohol. Dikeringkan dalam oven selama 8 jam, kemudian didinginkan dalam eksikator selama 30 menit, lalu ditimbang (a gram). Setelah itu diabukan dalam tanur listrik pada suhu $500^{\circ} \mathrm{C}$ selama tiga jam. Dibiarkan agak dingin, kemudian dimasukkan ke

$$
\text { Kadar serat }=\frac{a-b}{\text { Bobot serat }} \times 100 \%
$$

dalam eksikator selama 30 menit, lalu ditimbang (b gram). Kadar serat kasar dihitung dengan rumus :

\section{Analisis Data}

Pengaruh perlakuan terhadap unsur organoleptis dianalisis secara deskriptif. Untuk mengetahui pengaruh perlakuan terhadap tingkat preferensi lebah dan kandungan serat kasar dari MSM dilakukan analisis ragam. Beda pengaruh perlakuan diuji dengan uji kontras dan uji beda nyata jujur (BNJ). Bentuk hubungan antara perlakuan dengan jumlah pakan tambahan yang dikonsumsi oleh lebah dianalisis dengan menggunakan regresi linier.

\section{HASIL DAN PEMBAHASAN}

\section{Hasil Penelitian}

\section{Tingkat preferensi lebah terhadap} pakan tambahan.

Hasil analisis ragam menunjukkan bahwa perbedaan konsentrasi mengkudu dalam pakan berpengaruh nyata pada taraf nyata $5 \%$ terhadap rata-rata jumlah pakan tambahan yang dikonsumsi oleh lebah per hari, sedang perbedaan waktu pengamatan (minggu) dan perbedaan koloni memberikan pengaruh yang berbeda tidak nyata.

Secara umum, hasil uji kontras menunjukkan bahwa terdapat perbedaan yang sangat nyata antara preferensi lebah terhadap pakan yang tidak mengandung mengkudu dan

Tabel 1. Uji BNJ pada Taraf Nyata 0,05 untuk Tingkat Kesukaan Lebah

\begin{tabular}{cc}
\hline Perlakuan & $\begin{array}{c}\text { Jumlah Pakan yang Dikonsumsi Lebah Per Hari } \\
\text { (gram) }\end{array}$ \\
\hline A & $298,845 \mathrm{a}$ \\
B & $163,480 \mathrm{ab}$ \\
C & $49,248 \mathrm{~b}$ \\
D & $20,208 \mathrm{~b}$ \\
\hline
\end{tabular}

*) Huruf yang sama menyatakan berbeda tidak nyata pada taraf nyata 0,05 
pakan yang mengandung mengkudu. Selanjutnya, hasil uji BNJ (Tabel 1) menyatakan bahwa perbedaan yang nyata dari preferensi lebah terhadap pakan tambahan terjadi antara perlakukan $\mathrm{A}$ dengan $\mathrm{C}$ dan $\mathrm{D}$. Sedang perlakuan B berbeda tidak nyata dengan perlakuan lainnya.

\section{Sifat Organoleptis}

Hasil pengamatan terhadap warna madu yang dihasilkan menunjukkan bahwa MSM hasil dari A mempunyai warna yang lebih terang hasil dari B mempunyai warna "Bright reddish brown (2.5YR 5/8)", MSM hasil dari C mempunyai warna "Dark red (7.5R 3/4)" dan MSM hasil dari D mempunyai warna "Dark red (7.5R $3 / 6)^{\prime \prime}$

Adanya perbedaan warna pada MSM terutama yang dihasilkan oleh perlakuan B, C dan D dibandingkan dengan perlakuan $\mathrm{A}$ diduga adanya

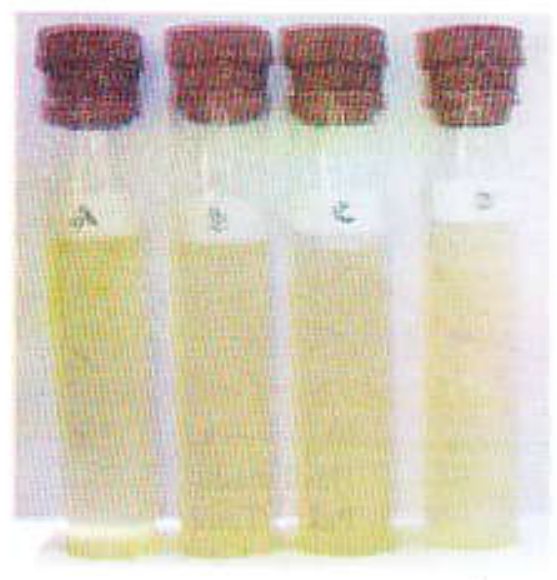

(a) Madu pakan dibandingkan dengan MSM dari perlakuan lainnya (Gambar 2). Ada kecenderungan bahwa semakin banyak kandungan mengkudu dalam campuran pakan akan menghasilkan warna madu yang semakin gelap.

Berdasarkan notasi Munsell, madu pakan $(\mathrm{P})$ mempunyai warna yang relatif sama, yaitu berwarna kuning dengan corak $5 \mathrm{Y}$ dan nilai $8 / 8$ ("Yellow (5Y 8/8)"). Untuk warna MSM hasil dari A mempunyai warna "Yellow orange (10YR 7/8)", MSM senyawa yang ada dalam mengkudu yang dikandung oleh masing-masing MSM yang dihasilkan. Menurut Sarwono (2001), asal dari bunga tanaman yang berbeda-beda mengakibatkan warna, aroma dan rasa madu juga berbeda-beda. Warna madu bervariasi mulai dari putih, kuning, sampai coklat kehitam-hitaman. Variasi warna ini tergantung pada

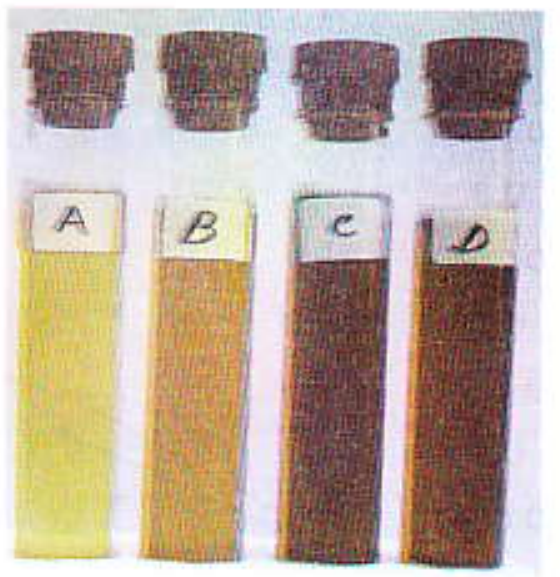

(b) Madu yang dihasilkan (MSM)

Gambar 2. Madu pakan dan madu yang dihasilkan oleh lebah 
komposisi zat warna yang terkandung di dalamnya. Zat warna yang membentuk madu adalah xantopil, dan karoten.

\section{Kandungan serat kasar MSM}

Hasil analisis kandungan serat kasar menunjukkan bahwa rata-rata kandungan serat kasar madu pakan sebesar $0,05 \%$, sedangkan kandungan serat kasar jus mengkudu sebesar $0,72 \%$. Kandungan serat kasar MSM yang dihasilkan lebih kecil dibandingkan dengan kandungan serat kasar pakan tambahan.

Selisih kandungan serat kasar antara pakan dan MSM berbanding lurus dengan kandungan mengkudu dalam pakan. Semakin tinggi kandungan mengkudu dalam pakan, semakin besar selisih kandungan serat kasar antara pakan tambahan dan MSM yang dihasilkan (Gambar 3).

\section{PEMBAHASAN}

Tingkat preferensi lebah terhadap pakan tambahan

Hasil penelitian membuktikan fakta lebah lebih menyukai pakan tambahan berupa madu tanpa mengkudu daripada pakan yang dicampur dengan sari mengkudu. Ada suatu kecenderungan yang semakin menurun dari jumlah pakan tambahan yang dikonsumsi oleh lebah dengan meningkatnya kandungan mengkudu yang ada dalam pakan tambahan. Bentuk hubungan antara kandungan mengkudu dalam pakan tambahan (X) dan rata-rata jumlah pakan yang dikonsumsi oleh lebah perhari (Y) adalah eksponensial dengan persamaan $\mathrm{Y}=304.143 \mathrm{e}^{-0.777 \mathrm{X}}$ atau $\ln \mathrm{Y}=5.717$ - $0.077 \mathrm{X}$ dengan koefisien determinasi (R2) sebesar 0,789 . Hal ini menyatakan bahwa bentuk hubungan tersebut sudah cukup memadai. Grafik dari persamaan tersebut dapat dilihat pada Gambar 1 .

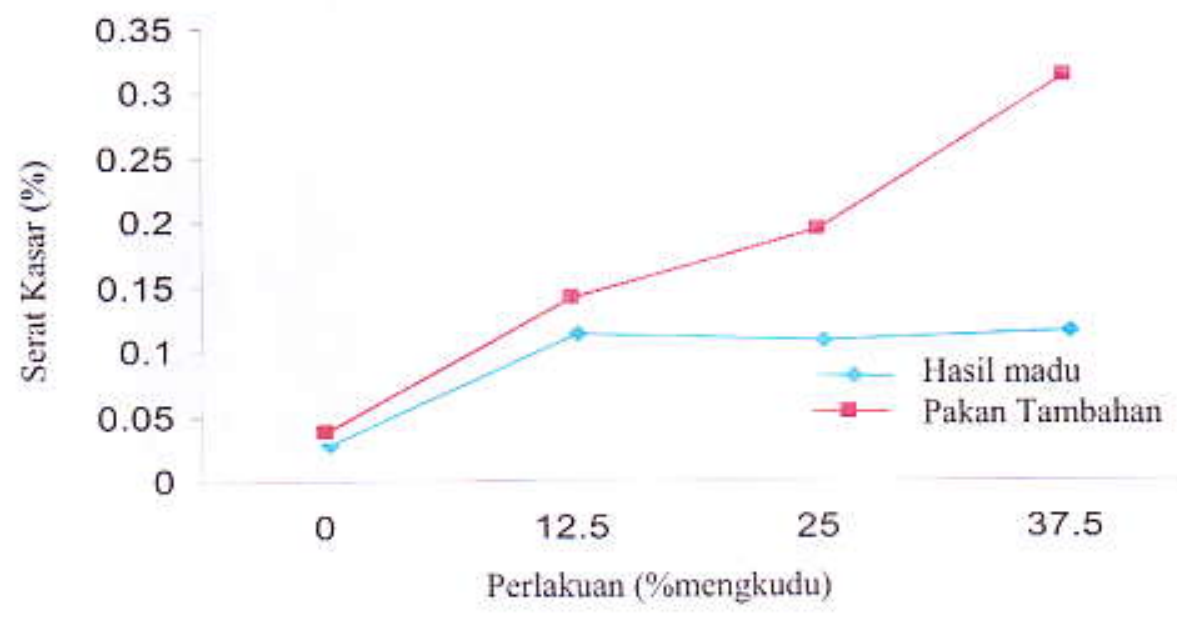

Gambar 3. Kandungan serat kasar pakan tambahan dan madu yang dihasilkan 


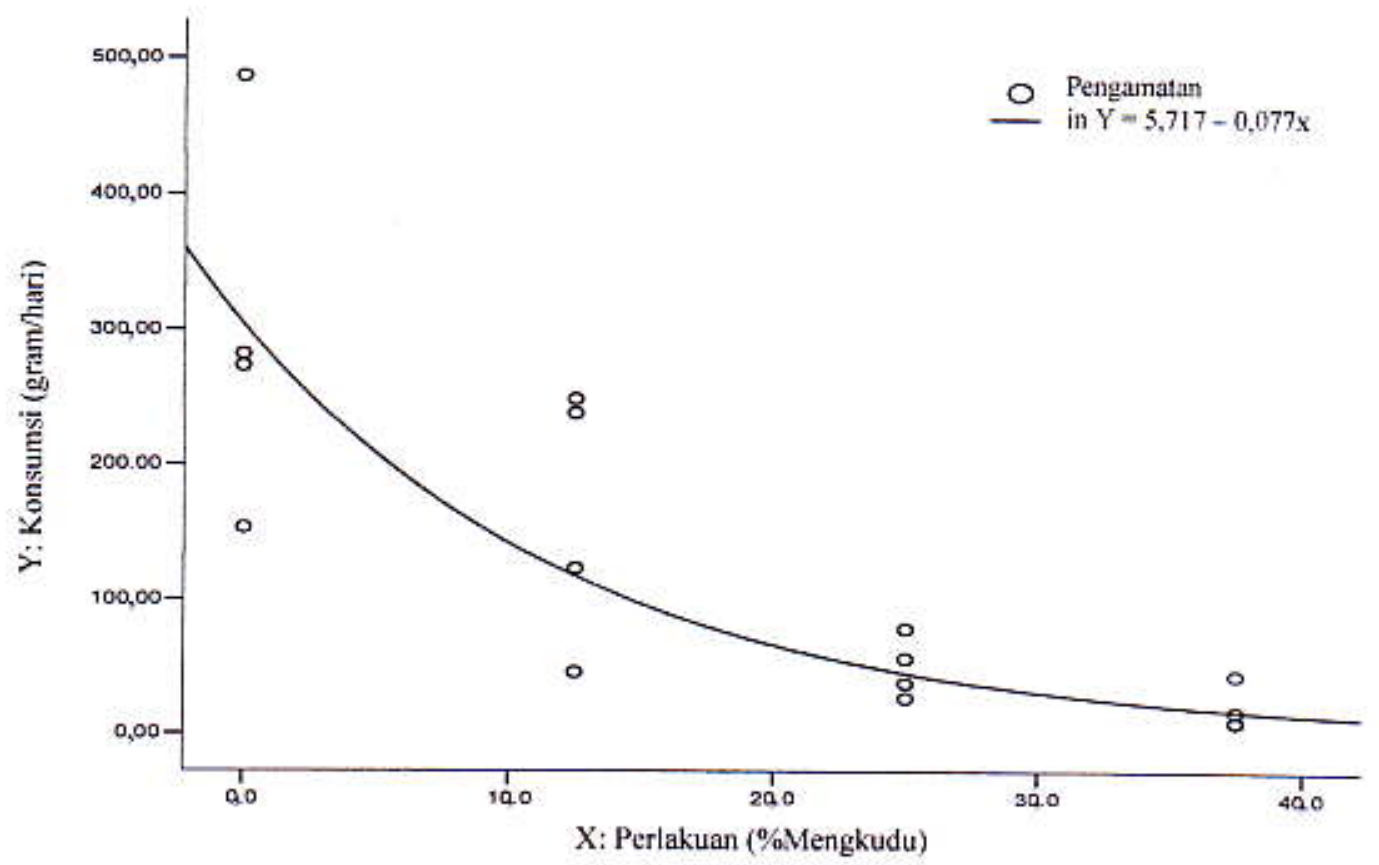

Gambar 1. Grafik hubungan antara kandungan mengkudu dan jumlah pakan yang dikonsumsi

\section{Sifat Organoleptis}

Perbedaan warna, aroma dan rasa dari MSM tidak tergantung pada jumlah pakan yang dikonsumsi tetapi dipengaruhi oleh kandungan mengkudu dalam pakan tambahan. Semakin banyak kandungan mengkudu dalam pakan tambahan menghasilkan madu yang warnanya semakin gelap, aroma madu makin memudar dan rasa yang makin asam. Secara alami, warna, aroma dan rasa madu ditentukan oleh asal bunga dari mana madu di peroleh. Warna madu bervariasi mulai dari putih, kuning, sampai coklat kehitam-hitaman. Variasi warna ini tergantung pada komposisi zat warna yang terkandung di dalam madu. Zat warna yang membentuk warna madu antara lain adalah xantopil, dan karoten (Sarwono 2001).
Perlakuan A menghasilkan MSM yang mempunyai warna kuning oranye, perlakuan $\mathrm{B}$ menghasilkan warna coklat kemerahan sedang perlakuan C dan D menghasilkan warna merah gelap.

Aroma madu mempunyai hubungan dengan warnanya. Perlakuan A menghasilkan aroma MSM seperti aroma madu pada umumnya. Perlakuan B menghasilkan MSM dengan aroma yang lebih tajam, sedangkan MSM hasil dari $\mathrm{C}$ dan $\mathrm{D}$ aroma madunya sudah mulai pudar. Hal ini diduga adanya komponen buah mengkudu yang mengeluarkan aroma yang sangat menyengat dalam MSM. Secara umum, semakin tajam aroma MSM, semakin gelap warnanya. Kenyataan ini didukung oleh Sumoprastowo \& Suprapto (1993), yang menyatakan 
bahwa aroma madu mempunyai hubungan dengan warnanya. Makin gelap warna madu, aromanya makin keras dan tajam.

Seperti halnya aroma, rasa MSM juga erat hubungannya dengan warnanya. MSM hasil dari A mempunyai rasa yang lebih manis dibandingkan dengan madu asal pakan tambahan. MSM hasil dari B mempunyai rasa manis yang sedikit agak asam, sedang MSM hasil dari C dan D mempunyai rasa manis asam. Jadi secara umum, semakin gelap warna MSM, semakin asam rasanya. Rasa asam yang ada pada MSM kemungkinan berasal dari jus mengkudu yang dicampurkan dalam pakan tambahan. Makin banyak kandungan jus mengkudu, makin tinggi kadar airnya. Makin tinggi kadar airnya makin cepat proses fermentasinya, sehingga memungkinkan kadar asam cukanya lebih tinggi.

\section{Kandungan serat kasar MSM}

Hasil analisis ragam menun- jukkan bahwa terdapat perbedaan yang sangat nyata dari pengaruh perlakuan. Selanjutnya uji kontras menyatakan bahwa perlakuan tanpa mengkudu menghasilkan MSM dengan kandungan serat kasar yang berbeda sangat nyata dengan perlakuan yang menggunakan mengkudu. Hal ini didukung oleh uji BNJ (Tabel 2) yang menyatakan bahwa kandungan serat kasar dalam MSM yang dihasilkan dari pakan yang mengandung mengkudu semuanya berbeda tidak nyata pada taraf nyata $5 \%$. Hal ini kemungkinan disebabkan oleh jumlah pakan yang dikonsumsi oleh lebah cenderung semakin menurun dengan meningkatnya kandungan mengkudu dalam pakan sehingga mempunyai pengaruh yang saling meniadakan terhadap jumlah serat dalam MSM. Adanya perbedaan kandungan serat MSM hasil dari A dengan MSM hasil dari B, C dan D merupakan suatu indikasi bahwa di dalam MSM hasil dari B, C dan D mengandung komponen mengkudu. $\mathrm{Hal}$ ini

Tabel 2. Uji BNJ pada Taraf Nyata 0,05 Kandungan Serat Kasar Pakan Tambahan dan Madu yang Dihasilkan

\begin{tabular}{ccc}
\hline & \multicolumn{2}{c}{ Madu yang Dihasilkan } \\
\cline { 2 - 3 } Perlakuan & $\begin{array}{c}\text { Kandungan serat kasar } \\
(\%)\end{array}$ & $\begin{array}{c}\text { Kandungan serat kasar } \\
(\%)\end{array}$ \\
\hline A & $0,04 \mathrm{a}$ & $0,03 \mathrm{a}$ \\
B & $0,14 \mathrm{~b}$ & $0,12 \mathrm{~b}$ \\
C & $0,19 \mathrm{c}$ & $0,12 \mathrm{~b}$ \\
D & $0,31 \mathrm{~d}$ & $0,13 \mathrm{~b}$ \\
\hline
\end{tabular}

*) Huruf yang sama menyatakan berbeda tidak nyata pada taraf nyata 0 . 
ditunjukkan oleh adanya kandungan serat MSM hasil dari B, C dan D yang jauh lebih tinggi dibandingkan dengan kandungan serat MSM hasil dari A.

\section{KESIMPULAN DAN SARAN}

Berdasarkan hasil dan pembahasan yang telah dilakukan pada bab sebelumnya, dapat disimpulkan halhal sebagai berikut :

1. Lebah A. mellifera kurang suka terhadap tambahan yang mengandung jus mengkudu.

2. Madu sari mengkudu mempunyai warna dasar kuning.

3. Madu sari mengkudu cenderung memiliki aroma dan rasa asam.

4. Kadar sari mengkudu dalam formula pakan tambahan kurang berarti dalam peningkatan kadar serat MSM.

\section{Saran}

Dalam upaya mengembangkan budidaya madu sari mengkudu dengan menggunakan metode cepat, disarankan untuk menggunakan larutan pakan tambahan dengan komposisi $37,5 \%$ madu, $12,5 \%$ mengkudu dan $50 \%$ air karena menghasilkan madu sari mengkudu yang mempunyai kandungan serat yang relatif tinggi dan rasa manis meskipun sedikit agak asam.

\section{UCAPAN TERIMAKASIH}

Kami mengucapka terimakasih tak terhingga kepada : Dirjen Dikti, Departemen Pendidikan dan Kebudayaan Republik Indonesia yang telah membiayai dan memfasilitasi penelitian ini, Lembaga Penelitian Universitas Hasanuddin, dan semua pihak yang telah berpartisipasi dalam penelitian ini.

\section{DAFTAR PUSTAKA}

loyrish N. 1978. Bees and People. Uni Soviet: Forlang Publishing.

Sarwono 2001. Lebah Madu. Tangerang: Agro Media Pustaka.

Sastrohamidjojo H. 1979. Kromatografi. Yogyakarta: Liberty.

Sumoprastowo RM, Suprapto RA. 1993. Beternak Lebah Madu Modern. Jakarta: Bhratara. 